\title{
Generation Means Analysis for Estimation of Genetic Parameters for Striga hermonthica Resistance in Maize (Zea mays L.)
}

\author{
Peter Okoth Mbogo ${ }^{1,2}$, Mathews Mito Dida ${ }^{1} \&$ Barrack Owuor $^{1}$ \\ ${ }^{1}$ Department of Applied Plant Sciences, School of Agriculture and Food Security, Maseno University, Kenya \\ ${ }^{2}$ Seedco Maize Breeding Station, Kitale, Kenya \\ Correspondence: Peter Okoth Mbogo, Agriseedco Limited, P.O. Box 616, 00621, Nairobi, Kenya. Tel: \\ 254-715-783-017. E-mail: petermbogo2002@yahoo.com
}

\author{
Received: May 5, 2015 Accepted: June 6, 2015 Online Published: July 15, 2015 \\ doi:10.5539/jas.v7n8p143 URL: http://dx.doi.org/10.5539/jas.v7n8p143
}

\begin{abstract}
Striga hermonthica is a parasitic weed species that causes considerable yield loss in susceptible maize cultivars in western Kenya. A generation means analysis was conducted to estimate gene effects influencing resistance/tolerance to Striga hermonthica in maize cultivars adapted to western Kenya. A resistant inbred line developed by Maseno University, MSMP1/P2 was crossed to Striga susceptible inbred line 5057. Experimental units comprised of resistant parent $\mathrm{P}_{1}$, susceptible parent $\mathrm{P}_{2}$, their $\mathrm{F}_{1}$ and $\mathrm{F}_{2}$ generations, and $\mathrm{BC}_{1} \mathrm{P}_{1}$ and $\mathrm{BC}_{1} \mathrm{P}_{2}$ generations. The six generations were evaluated under Striga sick plots at Nyahera during the short rains of 2012 and long rains of 2013. Field evaluation for entries were grown in a randomized complete block design with three replicates. The results showed significant differences among generations for emerged Striga, Striga damage rating and maize growth including Plant and Ear height. Most of the additive, dominance, additive $\mathrm{x}$ additive, additive $\mathrm{x}$ dominance and dominance $\mathrm{x}$ dominance effects were significant indicating the importance of the additive, dominance and epistatic modes of gene actions in controlling emerged Striga, Striga damage rating, plant and ear height. Most components conferring Striga tolerance behaved in a qualitative manner. Dominance effects had higher mean values over additive effects. Significant dominant genetic effects (d) for Striga emergence and Striga damage rating suggested preponderance of non-additive genetic effects in the inheritance of Striga tolerance. The results also reveal the involvement of duplicate epistasis where the dominance estimate and dominance $\mathrm{x}$ dominance interaction had opposite signs. The presence of duplicate type of gene interaction confirms the importance of dominance gene effects.
\end{abstract}

Keywords: maize, Zea mays, Striga hermonthica, gene action, dominance, additive, generation mean analysis

\section{Introduction.}

Striga hermonthica (Del.) Benth., is a menacing parasitic weed that belongs to the family Scrophulariaceae and constitutes one of the greatest biotic constraints to food crop production, undermining the struggle to attain food security and economic growth in Sub-Saharan Africa (Sauerborn, 1991). Continuous mono-cropping with no fallow in turn has led to a gradual increase in populations of Striga species, which have become a serious threat to cereal production (Ariga, 1996). It is noteworthy that areas that have Striga problems are generally also characterized by low productivity, a shortened or non-existent fallow period, low fertilizer inputs as well as non-pesticide use and lack of improved seeds (Abayo et al., 1997).

The most effective way to minimize the yield loss due to Striga infestation is to use resistant crop varieties (Verkleij \& Kuijper, 2000; Haussmann \& Hess, 2000; Rich \& Ejeta, 2008) because these do not require additional inputs such as labor and chemicals. Resistance to Striga refers to the ability of the host plant to stimulate the germination of Striga seeds but prevents the attachment of the parasite to its roots or to decimate the attached parasite (Badu-Apraku \& Akinwale, 2011). A tolerant genotype on the other hand germinates and supports as many Striga plants as the sensitive genotype but produces more grain yield and shows fewer Striga damage symptoms (Kim, 1994). When infested, the resistant genotype is able to support a significantly fewer Striga plants and produces a higher yield than a susceptible genotype (Dogget, 1988; Ejeta et al., 1992; Haussmann et al., 2000; Rodenburg et al., 2006). Resistance or tolerance to Striga is quantitatively inherited (Ejeta et al., 1997; Lane et al., 1997; Kim, 1994). Reports of genetic resistance to Striga have been documented in rice (Oryza sativa; Bennetzen et al., 2000; Gurney et al., 2006), sorghum (Sorghum bicolor; Maiti et al., 1984; 
Hess et al., 1992; Vogler et al., 1996; Haussmann et al., 2004) and maize (Adetimirin et al., 2000; Gethi \& Smith, 2004; Menkir, 2006). Identifying source germplasm with different resistance mechanisms can facilitate combining several resistance genes to obtain more durable and stable polygenic resistance to Striga in cereals (Ejeta et al., 2000; Menkir, 2006). Several studies have been conducted to characterize mechanisms of resistance to Striga in other crops, including cowpea (Vigna unguiculata; Riopel \& Timko, 1995), sorghum [Sorghum bicolor (L.) Moench] (Hess et al., 1992; Arnaud et al., 1999; Mohamed et al., 2003; Rich et al., 2004; Noubissie et al., 2012), rice (Harahap et al., 1993; Gurney et al., 2006; Jamil et al., 2011), pearl millet [pennisetum glaucum] (L.) R. Br] (Kountche et al., 2013) and maize [Zea mays L.] (Amusan et al., 2008; Karaya et al., 2012). However, this information on the nature of resistance to Striga is not readily available to farmers since they are only in journals and books (Atera et al., 2014). Maize resistance can be expressed through low stimulation of Striga seed germination (Gurney et al., 2003; Pierce et al., 2003; Kiruki et al., 2006), low haustorial induction (Gurney et al., 2003), avoidance through root architecture (fewer thin branches) (Amusan et al., 2008), escape by early maturity (Oswald \& Ransom, 2004), resistance to attachment (Amusan et al., 2008) and failure to support attached parasites (Lane et al., 1997; Gurney et al., 2003; Amusan et al., 2008). In maize, attempts have been made to introduce tolerance/resistance from both land races and wild relatives Zea diploperennis (teosinte) and Trypsacum dactyloides (Kling et al., 2000). ZD05, a progeny of backcrosses between International Institute of Tropical Agriculture (IITA) developed tropical maize germplasm and teosinte has been registered as Striga resistant line, TZSTR1108 (Menkir et al., 2006). These resistant and tolerant materials have fewer attached Striga hermonthica than susceptible lines and in addition show delayed parasitic post attachment development and higher mortality of attached parasites (Amusan et al., 2008). Another wild relative of maize, Trypsacum dactyloides (L.) has been shown to display post attachment resistance to Striga hermonthica and high level of tolerance (Hearne, 2009). However, breeding for resistance to Striga in maize, with scarcity of donor source and known mechanism of resistance, has been challenging (Amusan et al., 2008). Results of a few studies have shown that recurrent selection was effective in improving maize for Striga resistance (Menkir \& Kling, 2007; Badu-Apraku et al., 2006, 2008). Recurrent selection is a cyclical scheme designed to increase the frequency of favorable alleles in a population and has been widely used effectively to improve quantitative traits in maize breeding populations (Sprague \& Eberhart, 1977; Hallauer \& Miranda, 1988; Kling et al., 2000; Menkir \& Kling, 1999, 2007; Badu-Apraku et al., 2006, 2008). When inherited through additive gene action, the favorable genes are expected to make equal contribution to the improvement of the trait (Badu-Apraku et al., 2009). Better knowledge of the mode of gene action controlling the inheritance of resistance would enhance the identification and development of resistant varieties (Akanvou \& Doku, 1998). For the maize varieties adapted to and tolerant to Striga in western Kenya, there is no published report on the role of different gene action modes involved in their tolerance to the noxious weed. Therefore we conducted a generation mean analysis with the objective to estimate the magnitude of gene effects influencing tolerance to Striga hermonthica in a cross between Maseno university resistant maize inbred line MSP1/P2 and the susceptible inbred line 5057 from the IITA. Information about gene effects including additive, dominance gene effects (a and d) and the three types of non alleleic gene interactions, that is, additive $\mathrm{x}$ additive (aa), additive $\mathrm{x}$ dominance (ad) and dominance $\mathrm{x}$ dominance (dd) are very important in designing an effective gene deployment strategies in a resistance improvement program. Generation mean analysis is a simple and a useful technique for estimating these genetic effects as well as epistasis. The nature of epistasis is also useful in deciding breeding procedures to be adopted for the improvement of quantitative characters.

\section{Materials and Methods}

\subsection{Site Description}

The field studies were done at Maseno University of Kenya and at Nyahera in Kenya. Maseno university site is Striga free and lies along the Equator at latitude $0^{\circ}$, longitude $34^{\circ} 30^{\prime} \mathrm{E}$ at an altitude of 1515 metres above sea level. The soils at Maseno are well drained, extremely reddish brown and friable clay. The soils vary in color, consistence and texture. They are classified as dystric nitisols (Jaetzold et al., 1982). It experiences mean minimum and maximum annual temperatures of $15.4{ }^{\circ} \mathrm{C}$ and $29.9{ }^{\circ} \mathrm{C}$ respectively with an annual rainfall of between $1100-1500 \mathrm{~mm}$ (Jaetzold et al., 1982). Nyahera, a Striga hot spot, lies at latitude $34^{\circ} 53.452^{\prime} \mathrm{E}$, longitude $0^{\circ} 35.977^{\prime} \mathrm{N}$ at an altitude of 1490 metres above sea level. The soils are well drained, shallow to moderately deep dark yellowish brown to reddish brown, friable, stony sandy clay loam to gravelly sandy clay. They are classified as ferralic, humic and dystric cambisols (Jaetzold et al., 1982). The average annual rainfall is $1650 \mathrm{~mm}$ per annum (Jaetzold et al., 1982). The two sites have a bimodal type of rainfall where the first peak falls between April and August (Long rains season) and the second peak between September and December (short rains season). The short rains season, however are sometimes unreliable. 
Maseno site being Striga free was used to make crosses during the short rains of 2011 and the long rains of 2012. Evaluations were done at Nyahera under Striga infestation in the short rains of 2012 and the long rains of 2013.

\subsection{Maize Population Development}

Striga resistant maize inbred line developed by Maseno University, MSMP1/P2 was crossed to Striga susceptible inbred line 5057 from the International Institute of Tropical agriculture (IITA). The $\mathrm{F}_{1}$ generations were selfed to produce $\mathrm{F}_{2}$ generations, and $\mathrm{F}_{1}$ generations were crossed to both parents [resistant parent $\left(\mathrm{P}_{1}\right)$ and susceptible parents $\left(\mathrm{P}_{2}\right)$ ] to produce backcrosses of $\mathrm{F}_{1}$ for each parent $\left(\mathrm{BC}_{1} \mathrm{P}_{1}\right)$ and $\left(\mathrm{BC}_{1} \mathrm{P}_{2}\right)$ generations, respectively. Experimental units comprised populations of the six generations with details as follows: $\mathrm{P}_{1}=\mathrm{MSMP} 1 / \mathrm{P} 2, \mathrm{P}_{2}=$ $5057, \mathrm{~F}_{1}=\mathrm{MSMP} 1 / \mathrm{P} 2 \times 5057, \mathrm{~F}_{2}=\mathrm{MSMP} 1 / \mathrm{P} 2 \times 5057(\mathrm{selfed}), \mathrm{BC}_{1} \mathrm{P}_{1}=(\mathrm{MSMP} 1 / \mathrm{P} 2 \times 5057) \times \mathrm{MSMP} 1 / \mathrm{P} 2 ;$ $\mathrm{BC}_{1} \mathrm{P}_{2}=(\mathrm{MSMP} 1 / \mathrm{P} 2 \times 5057) \times 5057$.

\subsection{Field Evaluation and Experimental Design}

The six generations, $\mathrm{P}_{1}, \mathrm{P}_{2}, \mathrm{~F}_{1}, \mathrm{~F}_{2}, \mathrm{BC}_{1} \mathrm{P}_{1}$ and $\mathrm{BC}_{1} \mathrm{P}_{2}$ were evaluated under Striga sick plots at Nyahera during the short rains (September to December) of 2012 and long rains (April to August) of 2013. Experimental plots were ploughed and harrowed twice. Seeds were hand - sown one seed per hill. Field evaluations for entries were grown in a randomized complete block design in three replications. The experimental units were four row plots for the $\mathrm{P}_{1}, \mathrm{P}_{2}$, and $\mathrm{F}_{1}$ generations, a six row plot for the $\mathrm{BC}_{1} \mathrm{P}_{1}$ and $\mathrm{BC}_{1} \mathrm{P}_{2}$ generations, and an eight row plot for the $\mathrm{F}_{2}$ progeny generation. The length of the rows including 1 meter alleys was 5.1 meters with 0.75 meters between rows. Four, six and eight rows were used to reduce intergenotypic competition between plots of different generations and to sample adequately genotypic variability within generations. A compound fertilizer was applied at the rates of $60 \mathrm{~kg} \mathrm{~N}, 60 \mathrm{~kg} \mathrm{P}$, and $60 \mathrm{~kg} \mathrm{~K} \mathrm{ha}^{-1}$ at the time of sowing. Additional $60 \mathrm{~kg} \mathrm{~N} \mathrm{ha}^{-1}$ was applied as top dressing 4 weeks later after sowing. Hand hoe weeding was carried out prior to Striga emergence and thereafter weeds were hand pulled.

\subsection{Striga Severity Assessment and Assessment for Other Components of Resistance}

In each experiment, 15 plants from homogenous generations $\left(\mathrm{P}_{1}, \mathrm{P}_{2}\right.$ and $\left.\mathrm{F}_{1}\right), 30$ plants from backcross generations $\left[\left(\mathrm{BC}_{1} \mathrm{P}_{1}\right)\right.$ and $\left.\left(\mathrm{BC}_{1} \mathrm{P}_{2}\right)\right]$ and 60 plants from $\mathrm{F}_{2}$ generations were assessed for Striga severity, emerged Striga, plant height and ear height in each replicate.

\subsubsection{Striga Severity Assessment}

Each of the plants sampled for assessment were tagged. Striga damage syndrome was scored per plant using the scale of 1-5; where $1=$ no damage, indicating normal plant growth and high level of tolerance, and $5=$ complete collapse or death of the maize plant, that is, highly sensitive/intolerant. Emerged Striga counts and Striga damage rating at 8 and 10 weeks were recorded per plant.

\subsubsection{Plant Height and Ear Height $(\mathrm{cm})$}

These were measured as the distance from the base of the plant to the height of the first tassel branch and the node bearing the upper ear respectively.

\subsection{Data Analysis}

Generation means were calculated for each of the 6 generations on an individual plant basis using OPSTAT software .To determine the mode of inheritance of resistance/tolerance to Striga, Gamble's (1962) notation was used, where $[\mathrm{m}]=\mathrm{F}_{2}$ mean; additive gene effects $[\mathrm{a}]=\mathrm{B}_{1} \mathrm{CP}_{1}-\mathrm{BC}_{1} \mathrm{P}_{2} ;$ dominance gene effects $[\mathrm{d}]=-0.5 \mathrm{P}_{1}$ $0.5 \mathrm{P}_{2}+\mathrm{F}_{1}-4 \mathrm{~F}_{2}+2 \mathrm{BC}_{1} \mathrm{P}_{1}+2 \mathrm{BC}_{1} \mathrm{P}_{2}$; additive $\mathrm{x}$ additive gene effects [aa] $=-4 \mathrm{~F}_{2}+2 \mathrm{BC}_{1} \mathrm{P}_{1}+2 \mathrm{BC}_{1} \mathrm{P}_{2}$; additive $\times$ dominance gene effects $[\mathrm{ad}]=-0.5 \mathrm{P}_{1}+0.5 \mathrm{P}_{2}+\mathrm{BC}_{1} \mathrm{P}_{1}-\mathrm{BC}_{1} \mathrm{P}_{2}$ and dominance $\mathrm{x}$ dominance gene effects $[\mathrm{dd}]=$ $\mathrm{P}_{1}+\mathrm{P}_{2}+2 \mathrm{~F}_{1}+4 \mathrm{~F}_{2}-4 \mathrm{~B}_{1} \mathrm{CP}_{1}-4 \mathrm{~B}_{1} \mathrm{CP}_{2}$.

The model for a generation mean, $\mathrm{Y}$, is:

$\mathrm{Y}=\mathrm{m}+\alpha \mathrm{a}+\beta \mathrm{d}+\alpha 2 \mathrm{aa}+2 \alpha \beta \mathrm{ad}+\beta 2 \mathrm{dd}$

Where, $\mathrm{Y}$, the observed generation mean; $\mathrm{m}, \mathrm{F}_{2}$ mean; a, additive gene effects; $\mathrm{d}$, dominance gene effects; aa, additive $\mathrm{x}$ additive epistatic gene effects; ad, additive $\mathrm{x}$ dominance epistatic gene effects and dd, dominance $\mathrm{x}$ dominance epistatic gene effects. $\alpha$ and $\beta$ represent the coefficients for the genetic effects for the particular generation being estimated (Hayman, 1958; Mather \& Jinks, 1982). The estimates of least effective factors (gene) were obtained using Castle / Wright formula (Weber, 1950). 


\section{Results}

\subsection{Striga Data}

\subsubsection{Emerged Striga Counts}

There were significant differences $(\mathrm{P}<0.05)$ among the maize generations for emerged Striga count at 8 weeks after planting (Table 1). The mean Striga count was 1.1. The highly resistant generation with low (zero) Striga emergence was $P_{1}$. The maize generation with the highest number, 3.1, was the susceptible parent $P_{2}$.

Significant differences $(\mathrm{P}<0.05)$ were observed in the emerged Striga count amongst the maize generations for emerged Striga at 10 weeks after planting (Table 1). The mean Striga count was 2.3. The generation with the highest number, 6.2, was the susceptible parent $\mathrm{P}_{2}$. The resistant parent $\mathrm{P}_{1}$ had the least count of 0.4.

\subsection{Maize Response to Striga Infection}

\subsubsection{Striga Damage Rating at 8 Weeks after Planting}

Significant differences $(\mathrm{P}<0.05)$ were observed amongst the maize generations for Striga damage rating at 8 weeks after planting (Table 1). Striga damage ratings ranged from 1.1 to 2.7. The mean rating was 1.6. The susceptible parent $P_{2}$ had the highest damage rating of 2.7 on the scale of 1-5, whereas the resistant parent $P_{1}$ had the lowest damage score of 1.1. This was however not significantly different from $\mathrm{F}_{1}, \mathrm{BC}_{1} \mathrm{P}_{1}$ and $\mathrm{BC}_{1} \mathrm{P}_{2}$ generations. The susceptible parent damage score rating of 2.7 was significantly different from the rest of the generations.

\subsubsection{Striga Damage Rating at 10 Weeks after Planting}

There were significant differences $(\mathrm{P}<0.05)$ among the maize generations for Striga damage rating at 10 weeks (Table 1). The mean rating was 2.3. The susceptible parent $P_{2}$ had the worst score of 3.6 whereas the resistant parent, $\mathrm{P}_{1}$ had the best score of 1.1. $\mathrm{F}_{1}$ generation was similar to $\mathrm{BC}_{1} \mathrm{P}_{1}$ but significantly different from $\mathrm{P}_{1}, \mathrm{P}_{2} \mathrm{~F}_{2}$ and $\mathrm{BC}_{1} \mathrm{P}_{2}$. Among the segregating generations, $\mathrm{F}_{2}$ had the highest score followed by $\mathrm{BC}_{1} \mathrm{P}_{2}$ and $\mathrm{BC}_{1} \mathrm{P}_{1}$ respectively. The means for Striga counts and Striga damage ratings for $\mathrm{B}_{1} \mathrm{CP}_{2}$ generations were skewed towards the susceptible parent $\mathrm{P}_{2}$ whereas the $\mathrm{BC}_{1} \mathrm{P}_{1}$ generations were skewed towards the resistant parent $\mathrm{P}_{1}$.

\subsubsection{Plant Height}

There were significant differences $(\mathrm{P}<0.05)$ among the generations for plant height (Table 1). Plant heights ranged from 82.3 to $134.4 \mathrm{~cm}$. The mean plant height amongst the generations was $99 \mathrm{~cm}$. The resistant parent $\mathrm{P}_{1}$ had the highest figure of $134.4 \mathrm{~cm}$ whereas the susceptible parent $\mathrm{P}_{2}$ had the lowest value of $82.3 \mathrm{~cm}$. This however was not significantly different from the height of the segregating $\mathrm{F}_{2}$ and $\mathrm{BC}_{1} \mathrm{P}_{2}$ generations at 84.7 and $85.9 \mathrm{~cm}$ respectively.

\subsubsection{Ear Height}

There were significant differences amongst the generations for ear height. The mean ear height was $43.6 \mathrm{~cm}$. The ear heights ranged from 34.5 to $60.3 \mathrm{~cm}$. The resistant Parent $\mathrm{P}_{1}$ had the highest ear placement at 60.3 centimeters whereas the susceptible Parent, $\mathrm{P}_{2}$ had the ear placement at 36.1 centimeters. The back cross to the susceptible parent $\mathrm{BC}_{1} \mathrm{P}_{2}$ had the lowest ear placement of $34.5 \mathrm{~cm}$. The ear heights for the susceptible parent $\mathrm{P}_{2}$, $\mathrm{F}_{2}$ and backcross to the resistant parent $\mathrm{BC}_{1} \mathrm{P}_{1}$ were however not significantly different. 
Table 1. Means of Striga counts, Striga damage ratings, plant and ear height of $\mathrm{P}_{1}, \mathrm{P}_{2}$ and $\mathrm{F}_{1}, \mathrm{~F}_{2}, \mathrm{~B}_{1} \mathrm{CP}_{1}, \mathrm{BC}_{1} \mathrm{P}_{2}$ generations

\begin{tabular}{|c|c|c|c|c|c|c|}
\hline \multicolumn{7}{|c|}{ Variable } \\
\hline \multirow{2}{*}{ Generation } & \multicolumn{2}{|c|}{ Striga Count } & \multicolumn{2}{|c|}{ Striga Damage Rating } & \multirow{2}{*}{$\mathrm{PH}$} & \multirow{2}{*}{ EH } \\
\hline & 8 weeks & 10 weeks & 8 weeks & 10 weeks & & \\
\hline $\mathrm{P}_{1}$ & $0.0^{\mathrm{c}}$ & $0.4^{\mathrm{e}}$ & $1.1^{\mathrm{c}}$ & $1.1^{\mathrm{e}}$ & $134.4^{\mathrm{a}}$ & $60.3^{\mathrm{a}}$ \\
\hline$P_{2}$ & $3.1^{\mathrm{a}}$ & $6.2^{\mathrm{a}}$ & $2.7^{\mathrm{a}}$ & $3.6^{\mathrm{a}}$ & $82.3 \mathrm{~d}$ & $36.1^{b c}$ \\
\hline$F_{1}$ & $0.1^{\mathrm{c}}$ & $1.5^{\mathrm{cd}}$ & $1.4^{\mathrm{c}}$ & $1.7^{\mathrm{d}}$ & $109.8^{\mathrm{b}}$ & $50.9^{\mathrm{ab}}$ \\
\hline $\mathrm{F}_{2}$ & $1.4^{\mathrm{b}}$ & $2.0^{b c}$ & $1.8^{\mathrm{b}}$ & $2.8^{\mathrm{b}}$ & $85.9^{\mathrm{d}}$ & $42.1^{b c}$ \\
\hline $\mathrm{BC}_{1} \mathrm{P}_{1}$ & $0.3^{\mathrm{c}}$ & $0.7^{\mathrm{de}}$ & $1.3^{\mathrm{c}}$ & $1.7^{\mathrm{d}}$ & $96.8^{\mathrm{c}}$ & $37.5^{b c}$ \\
\hline $\mathrm{BC}_{1} \mathrm{P}_{2}$ & $1.5^{\mathrm{b}}$ & $2.8^{\mathrm{b}}$ & $1.1^{\mathrm{c}}$ & $2.1^{\mathrm{c}}$ & $84.7^{\mathrm{d}}$ & $34.5^{\mathrm{c}}$ \\
\hline Mean & 1.1 & 2.3 & 1.6 & 2.2 & 99.0 & 43.6 \\
\hline $\mathrm{CV}(\%)$ & 1.1 & 0.9 & 0.4 & 0.4 & 0.2 & 0.2 \\
\hline $\mathrm{SE} \pm$ & 0.5 & 0.9 & 0.3 & 0.4 & 8.2 & 4.1 \\
\hline Std & 1.2 & 2.1 & 0.6 & 1.0 & 20.1 & 10.1 \\
\hline Mid-parent (m) & 1.5 & 3.1 & 1.9 & 2.4 & 108.1 & 48.2 \\
\hline
\end{tabular}

Note. Means followed by the same letter within columns do not differ significantly according to DMRT.

$\mathrm{P}_{1}=$ resistant Parent (MSMP1/P2); $\mathrm{P}_{2}=$ Susceptible parent (5057); $\mathrm{BC}_{1} \mathrm{P}_{1}=$ Backcross to resistant parent; $\mathrm{BC}_{1} \mathrm{P}_{2}$ $=$ Backcross to susceptible parent. $\mathrm{PH}=$ Plant height; $\mathrm{EH}=$ Ear height; SE \pm , Standard error of the mean; Std, Standard deviation.

\subsection{Correlation between Striga Damage Rating and Plant Height of the Maize Generations}

Figures 1 and 2 are the correlation plots of Striga damage rating and plant height of the maize generations of the cross between $\mathrm{P}_{1}(\mathrm{MSMP} 1 / \mathrm{P} 2)$ and $\mathrm{P}_{2}(5057)$. The correlation was negative $(\mathrm{r}=-0.56)$ and the coefficient of the relationship $\left(\mathrm{R}^{2}\right)$ was 0.3 at 8 weeks after planting (WAP). The same negative correlation scenario $(r=-0.75)$ and $\left(\mathrm{R}^{2}=0.57\right)$ was observed at 10 WAP.

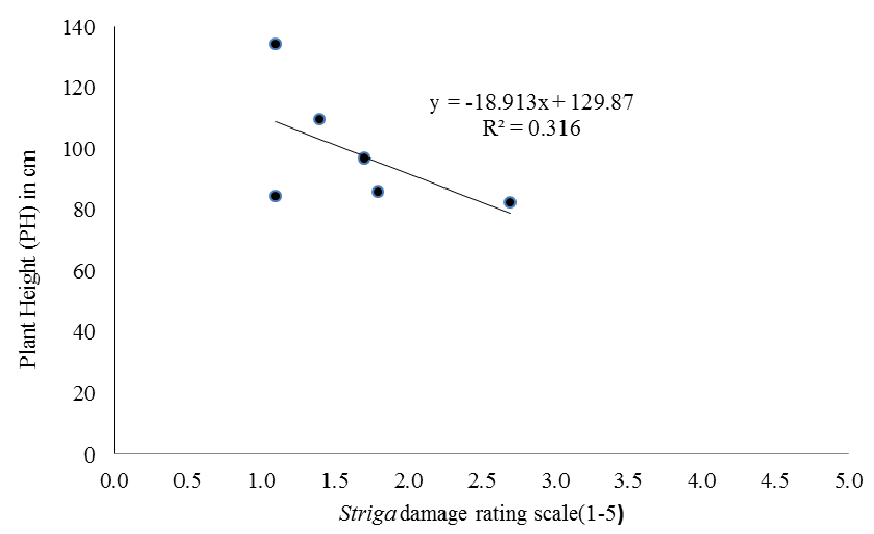

Figure 1. Linear correlation between plant height of the generations and Striga damage rating at 8 weeks after planting 


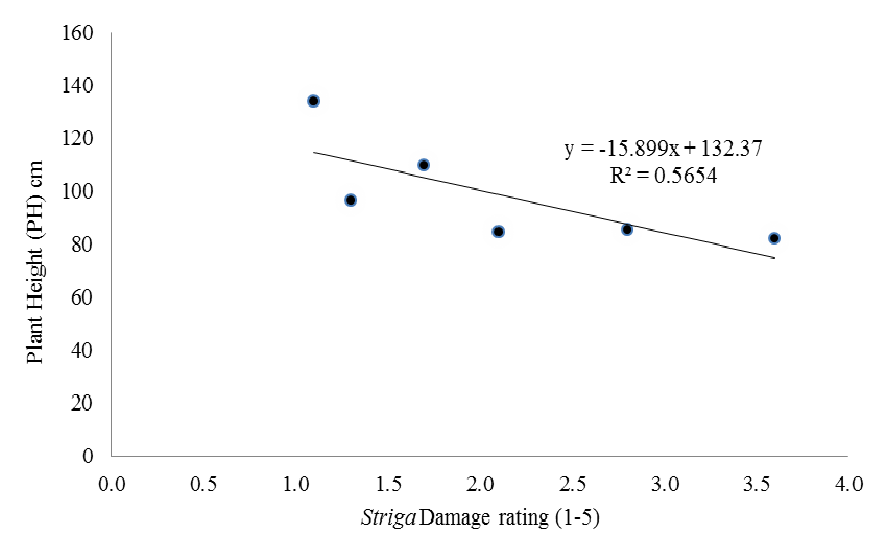

Figure 2. Linear correlation between plant height of the generations and Striga damage rating at 10 weeks after planting

\subsection{Correlation between Striga Damage Rating and Ear Height of the Maize Generations.}

The estimates of linear correlation was negative $(r=-0.48$ and $r=-0.56)$ at 8 and 10 WAP respectively (Figures 3 and 4$)$. The coefficient of determination $\left(\mathrm{R}^{2}\right)$ was 0.23 and 0.31 respectively.

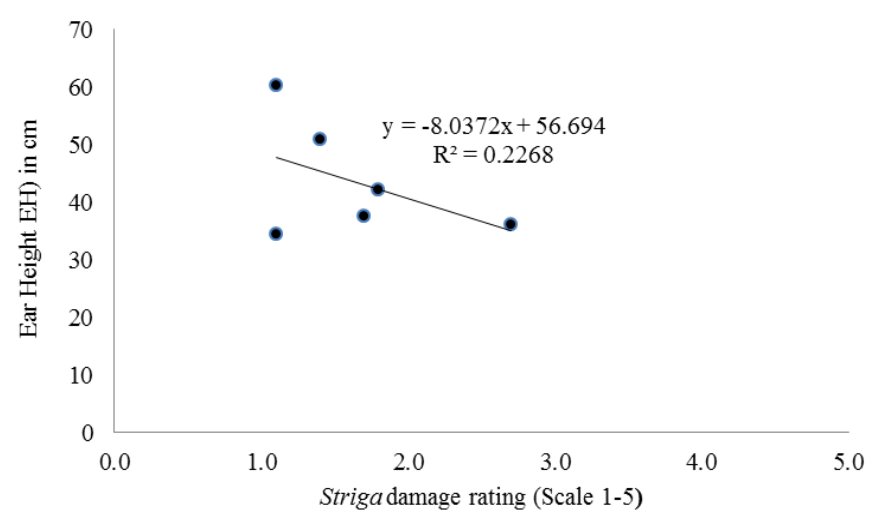

Figure 3. Linear correlation between Ear height of the generations and Striga damage rating at 8 weeks after planting

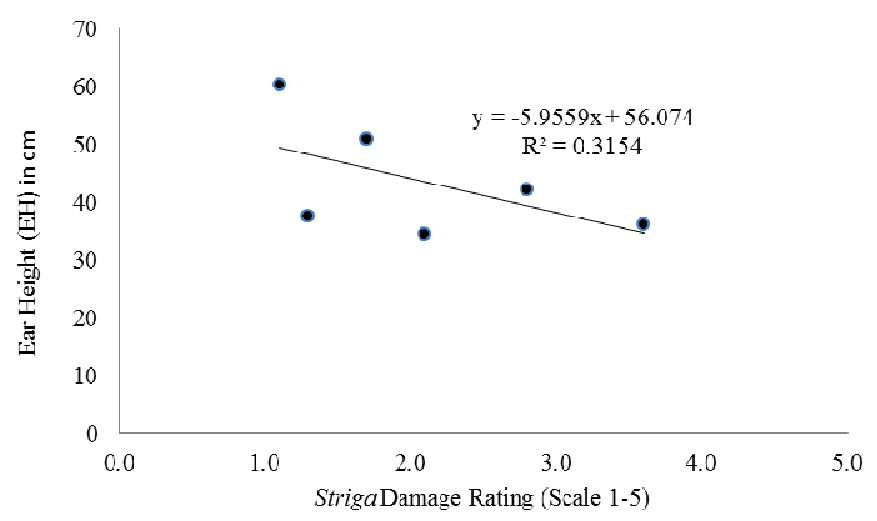

Figure 4. Linear correlation between Ear height of the maize generations and Striga damage rating at 10 weeks after planting 


\subsection{Estimates of Genetic Components}

Estimates of the six parameters, i.e. additive (a), dominance (d), additive $\mathrm{x}$ additive (aa), additive $\mathrm{x}$ dominance $(\mathrm{ad})$, dominance $\mathrm{x}$ dominance $(\mathrm{dd})$ and $\mathrm{F}_{2}$ means $(\mathrm{m})$ are presented in Table 2. The results indicated that the mean effects $(\mathrm{m})$ were highly significant for the variables.

Table 2. Estimates of genetic components of mean for various traits of the cross $\mathrm{P}_{1}(\mathrm{MSMP} 1 / \mathrm{P} 2) \times \mathrm{P}_{2}(5057)$ of maize under Striga infestation

\begin{tabular}{lllllll}
\hline Variable & $\mathrm{m}$ & {$[\mathrm{a}]$} & {$[\mathrm{d}]$} & {$[\mathrm{aa}]$} & {$[\mathrm{ad}]$} & {$[\mathrm{dd}]$} \\
\hline Striga Count 8 & $1.35 \pm 0.12^{* *}$ & $-1.15 \pm 0.13^{* *}$ & $-3.33 \pm 0.57^{*}$ & $-1.90 \pm 0.55^{*}$ & $0.83 \pm 0.40^{*}$ & $1.80 \pm 0.79^{*}$ \\
Striga Count 10 & $1.95 \pm 0.12^{* *}$ & $-2.15 \pm 0.29^{* *}$ & $-2.53 \pm 0.85^{*}$ & $-0.77 \pm 0.74^{\mathrm{ns}}$ & $1.50 \pm 0.82^{\mathrm{ns}}$ & $3.27 \pm 1.50^{*}$ \\
Striga Damage Rating 8 & $1.77 \pm 0.12^{* *}$ & $0.63 \pm 0.11^{* *}$ & $-1.93 \pm 0.52^{* *}$ & $-1.40 \pm 0.51^{* *}$ & $2.93 \pm 0.26^{* *}$ & $2.27 \pm 0.68^{* *}$ \\
Striga Damage Rating 10 & $2.75 \pm 0.11^{* *}$ & $-0.82 \pm 0.08^{* *}$ & $-4.85 \pm 0.50^{* *}$ & $-4.23 \pm 0.48^{* *}$ & $0.87 \pm 0.22^{* *}$ & $5.63 \pm 0.62^{* *}$ \\
Plant Height $(\mathrm{cm})$ & $85.85 \pm 2.46^{* *}$ & $12.08 \pm 2.25^{* *}$ & $21.10 \pm 12.11^{\mathrm{ns}}$ & $19.70 \pm 10.81^{\mathrm{ns}}$ & $-27.97 \pm 7.79^{* *}$ & $53.47 \pm 17.24 * *$ \\
Ear Height $(\mathrm{cm})$ & $42.1 \pm 1.86^{* *}$ & $2.95 \pm 1.38^{*}$ & $-21.72 \pm 8.39^{* *}$ & $-24.43 \pm 7.92^{* *}$ & $-18.27 \pm 4.17^{* *}$ & $78.63 \pm 10.77^{* *}$ \\
\hline
\end{tabular}

Note. $\mathrm{m}: \mathrm{F}_{2}$ means; $\mathrm{ns}, * *, *=$ non-significant, Significant at $1 \%$ and $5 \%$ probability level, respectively; [a], [d], [aa], [ad], [dd] = net directional effects of loci contributing to additive, dominance, additive $\mathrm{x}$ additive, additive $\mathrm{x}$ dominance, and dominance $\mathrm{x}$ dominance components, respectively.

From the experiment, all kinds of gene effects are significant $(\mathrm{P}<0.05)$, except additive $\mathrm{x}$ additive, additive $\mathrm{x}$ dominance for emerged Striga count at 10 weeks after planting and dominance, additive $\mathrm{x}$ additive effects for plant height which were not significant. Among the interactions, dominance $\mathrm{x}$ dominance interactions (dd) are larger than (aa) and (ad) except for Striga damage rating at 8 weeks after planting while among the main effects, dominance (d) is greater than the additive (a) component. The (d) and (dd) are in opposite directions except for plant height hence the nature of epistasis is duplicate. The (d) is negative, whereas (dd) is positive.

The additive gene effects (a) were positive and highly significant for Striga damage rating at 8 weeks. This was the same for plant height and ear height. Meanwhile negative significant values for these parameters were detected for emerged Striga count at 8,10 weeks after planting as well as for Striga damage rating at 10 weeks.

With regard to dominance gene effects (d) negative values were observed for Striga count 8, Striga count 10, Striga damage rating at 8 , Striga damage rating at 10 weeks and Ear height. Positive and non-significant gene effects were observed for plant height.

With respect to additive $\mathrm{x}$ additive type gene action, positive and non-significant effects were observed for plant height. Negative and non-significant effects were observed for Striga count at 10 weeks. Negative and significant effects were observed for Striga count at 8 weeks. Striga damage rating at 8 and 10 weeks and ear height, also exhibited significant additive and dominance gene effects.

Additive $\mathrm{x}$ dominance gene effects (ad) were found to be positive and significant for Striga count 8 and Striga damage rating at 8 and 10 weeks. Emerged Striga count at 10 weeks was positive and non-significant. Plant and Ear heights had negative and highly significant effects.

Concerning the dominance $\mathrm{x}$ dominance type of gene action, (dd), positively significant and highly significant effects were detected for all the variables.

\subsection{Estimates of the Number of Genes.}

The estimated number of genes controlling various traits in both crosses is presented in Table 3. Considering Castle-Wright's formular for estimation and crosses the number of genes responsible for emerged Striga and Striga damage rating as well as ear height was below one, whereas the number controlling plant height was approximately 3.0. 
Table 3. Estimates of the number of genes for the various traits in the cross $P_{1} \times P_{2}$

\begin{tabular}{ll}
\hline Trait & Formular (Castle-Wright's) \\
\hline Striga count at 8 weeks & 0.781 \\
Striga count at 10 weeks & -4.553 \\
Striga damage rating at 8 weeks & 0.629 \\
Striga damage rating at 10 weeks & 0.685 \\
Plant Height $(\mathrm{cm})$ & 2.627 \\
Ear Height $(\mathrm{cm})$ & 0.284 \\
\hline
\end{tabular}

\section{Discussion}

The mean Striga emergence and Striga damage ratings for the Striga resistant parent was significantly lower than the susceptible parent $\mathrm{P}_{2}$. This result shows that plant resistance to Striga was manifested and expressed by a lower number of emerged parasitic plants and less damage sustained by the host. It also suggests that screening progenitors was effective in differentiating the resistant from susceptible inbred lines. These results are consistent with the observations reported in maize (Kim et al., 1999) and sorghum (Oliver et al., 1991; Arnaud et al., 1999).

The means for emerged Striga counts at 8 and 10 weeks after planting and Striga damage rating at 10 weeks after planting for $\mathrm{BC}_{1} \mathrm{P}_{1}$ were skewed towards the resistant parent $\mathrm{P}_{1}$. This indicates that several genes could be involved in Striga resistance/tolerance. When backcross to the susceptible parent $\left(\mathrm{BC}_{1} \mathrm{P}_{2}\right)$ was performed, population distribution skewed towards the susceptible parent $\mathrm{P}_{2}$ (5057). In general, backcrossing to susceptibility increases frequency of alleles for susceptibility. Backcrossing to resistant parent increases alleles for resistance hence skews towards resistant direction. However, the presence of transgressive segregants that perform better or worse than parents do exist in this study. Transgressive segregants were observed in $\mathrm{BC}_{1} \mathrm{P}_{2}$ population which resulted in more resistant plants than the susceptible parent $\mathrm{P}_{2}(5057)$ for the Striga damage rating at 8 weeks.

Plant and Ear heights were negatively correlated with Striga damage rating which accounted for 30 and 57 percent of the variance in plant height at 8 and 10 weeks. On the other hand, Striga damage rating accounted for 23 and 30 percent of the variance in Ear height at 8 and 10 weeks. This is not unusual since susceptibility to Striga is manifested by decreased plant and ear height and the converse is true (Nagawa, 1991; Reda \& Kabebe, 1994; Mbasa, 1994). This scenario is supported by Akanvou et al. (1997) who reported a negative genetic correlation between plant height, Striga count, Striga rating and ear height. According to Akanvou and Doku (1998) negative association are expected since Striga reduces yield through its adverse effects on the physiology of the infested plants.

Estimates of the six parameters, i.e. additive (a), dominance (d), additive $\mathrm{x}$ additive (aa), additive $\mathrm{x}$ dominance (ad) and dominance $\mathrm{x}$ dominance and $\mathrm{F}_{2}$ means $(\mathrm{m})$ presented in Table 2 indicate that the mean effects $(\mathrm{m})$ were highly significant for the variables indicating that all the variables except plant height, are qualitatively inherited. Striga resistance in maize, reported to date, appears to be qualitative and recessive in nature (Lane et al., 1997; Oswald \& Ransom, 2004; Gethi \& Smith, 2004) qualities that may further ensure its stability (Rispail et al., 2007). Other reports also suggest that Striga resistance is controlled by relatively few genes with additive effects (Shinde \& Kulkarni, 1982; Vasudeva Rao et al., 1982). On the contrary Lane et al. (1997); Ejeta (2007); Haussmann et al. (2004) reported that resistance/tolerance to Striga was quantitatively inherited.

Higher mean values of dominance effects over additive effects, significant dominant genetic effects (d) for Striga emergence and Striga damage rating suggested a preponderance of non-additive genetic effects in the inheritance of Striga tolerance. This is in agreement with Kim (1994), who reported the importance of both additive and non-additive effects for Striga emergence in a di-allele study. This is also in agreement with Akanvou et al. (1997), who reported the preponderance of non-additive genetic effects for Striga emergence. On the contrary, Gethi and Smith (2004), reported that additive gene effects were more important than non-additive gene effects in the expression of all the resistance traits measured.

Gene interaction is considered to be complementary when the (d) and (dd) estimates have the same signs and to be duplicating when the signs differ (Mather \& Jinks, 1982). Gene interactions in this study were of duplicate type except for plant height which was complementary. This is contrary to Azizi et al. (2006), who reported duplicate type of non-allelic interaction for plant height in maize. The presence of duplicate type of gene 
interaction confirms the importance of dominance effects.

The additive gene effects (a) were positive and highly significant for Striga damage rating at 8 weeks, plant height and ear height. Meanwhile negative and significant values were detected for emerged Striga count at 8, 10 weeks after planting and Striga damage rating at 10 weeks. The results indicate that selection for Striga tolerance, plant and ear height are important in early generations. The negative and significant values mean that the materials that were used in the study have decreasing alleles for Striga tolerance and selection to improve it could be effective. One such effective way is to use the recurrent selection methods that capitalize on additive gene action for the screening of segregating families (Badu-Apraku et al., 2013). This should facilitate the accumulation of resistance/tolerance genes to develop germplasm with multigenic resistance/tolerance that could be effective and durable over time (Berner et al., 1995; Menkir \& Kling, 2007; Badu-Apraku et al., 2012).

With regard to dominance gene effects (d) negative values were observed for Striga count 8, Striga count 10, Striga damage rating at 8, Striga damage rating at 10 weeks and Ear height. This means that the alleles responsible for low values for Striga tolerance and ear height were dominant over the alleles controlling high values. Positive and non-significant gene effects were observed for plant height indicating the presence of dominant gene effect in the inheritance of plant height.

With respect to additive $\mathrm{x}$ additive (aa) type gene effects, positive and non-significant effects were observed for plant height. This means that early selection for plant height might be effective for Striga breeding. Negative and non-significant effects were observed for Striga count at 10 weeks. Negative and significant effects were observed for Striga count at 8 weeks, Striga damage rating at 8 and 10 weeks as well as ear height. This means that early generation selection for Striga tolerance simultaneous with ear height might not be an effective strategy in a Striga breeding program.

Additive $\mathrm{x}$ dominance type gene effects (ad) were found to be positive and significant for Striga count 8 and Striga damage rating at 8 and 10 weeks. Emerged Striga count at 10 weeks was positive but non-significant. Plant and Ear heights had negative but highly significant effects. Negative sign of interaction suggest an interaction between increasing and decreasing alleles, thus providing evidence of dispersion of genes in the inbred parents (Mather \& Jinks, 1982). Yi-Hong Wang et al. (2014) reported that both additive and dominant gene action are involved in Striga resistance under conditions of Striga infestation.

Concerning the dominance $\mathrm{x}$ dominance (dd) gene action, positive and highly significant effects were detected for all the variables. Positive and significant results confirm the important role of dominance $\mathrm{x}$ dominance gene interactions in the genetic system which controls Striga emergence, Striga tolerance, plant and ear heights.

For estimation of the number of effective factors, differences between parents and variation in $\mathrm{F}_{2}$ and backcrosses are needed. The Castle/Wright formula (Weber, 1950) was used to estimate the number of effective factors. With regard to Striga count, Striga damage rating and ear height an estimate of genes number was below one. These values should be considered as one and probably more. This may be due to the existence of interaction between pertinent non-allelic genes. With regard to plant height estimates of the effective factors when using Castle/Wright was 3.0 suggesting that the parental varieties differed in three pairs of genes. Thus, the number of effective factors might not be the actual number of genes due to the existence of interaction of non-allelic between the pertinent genes and dominance. This result is in accordance with that reported by Swamy Rao (1979) who reported that plant height was under the control of polygenes. The more than one gene responsible for the trait plant height, in the cross, stipulates polygenic inheritance of this trait in maize. The genes controlling quantitative traits could be linked and therefore segregate as a group or as an effective factor (Milus \& Line, 1986).

The negative Castle-Wright estimates for Striga count at 10 weeks are probably due to violations of the assumptions of the Castle-Wright estimator. The Castle-Wright equation assumes fixed differences between the parents, additive gene action, unlinked loci, and equality of allelic effects (Lynch \& Walsh, 1998). The assumption most likely violated is that of additive gene action, especially since dominance calculation indicates partial dominance for the trait examined (Table 3).

\section{Conclusion}

The estimates of number of genes involved and mode of gene action is important in deciding the breeding procedure for maize improvement under Striga infestation. A method that involves accumulation of favorable genes for the improvement of the trait under selection would be ideal. When inherited through additive gene action the favorable genes are expected to make equal contribution to the improvement of the trait. 


\section{Acknowledgements}

The authors would like to thank Maseno University and Mr. Onyango Baridi of Nyahera, Kenya for providing land where these materials were tested. Special thanks go to IITA and Prof. Mathews Dida for providing the inbred lines used in this study. This work was funded by a grant ( $3^{\text {rd }}$ call) from Kenya National Commission for Science, Technology and Innovation.

\section{References}

Abayo, G. O., English, E., Eplee, R. E., Kanampiu, F. K., Ransom, J. K., \& Gressel, J. (1998). Control of parasitic witchweeds (Striga spp) on corn (Zea mays) resistant to acetolactate synthase inhibitors. Weed Science, 46, 459-466.

Adetimirin, V. O, Kim, S. K., \& Akenvou, M. E. (2000). Expression of mature plant resistance to Striga hermonthica in maize. Euphytica, 115, 149-158. http://dx.doi.org/10.1023/A:1004006115082

Akanvou, E., Doku, V., \& Kling, J. (1997). Estimates of genetic variances and interrelationships of traits associated with Striga resistance in maize. African Crop Science Journal, 5(1), 1-8. http://dx.doi.org/10.4314/acsj.v5i1.27864

Akanvou, L., \& Doku, E. V. (1998). Heritability of traits associated with Striga [Striga hermonthica (Del.) Benth.] resistance in an open pollinated maize population. African Crop Science Journal, 6(2), 129-135. http://dx.doi.org/10.4314/acsj.v6i2.27808

Amusan, I. O., Richi, P. J., Menkir, A., Housely, T., \& Ejeta, G. (2008). Resistance to Striga hermonthica in a maize inbred line derived from Zea diploperennis. New Phytologist, 178, 157-166. http://dx.doi.org/10.1111/j.1469-8137.2007.02355.x

Arnaud, M. C., Veronesi, C., \& Thalouarn, P. (1999). Physiology and histology of resistance to Striga hermonthica in Sorghum bicolor var. Framida. Australian Journal of Plant Physiology, 26, 63-70. http://dx.doi.org/10.1071/PP98070

Ariga, E. S. (1996). Isolation and bioassay of Striga hermonthica seed germination Stimulants from non-host crops and field testing for control efficiency (Ph.D. Thesis, p. 158). University of Nairobi, Kenya.

Atuti, A. A., Onyango, J. C., Thanh, P. T., Ishii, T., \& Itoh, K. (2014). Identification of QTL for Striga hermonthica Resistance Using Backcross Population Derived from a Cross between Oryza sativa (cv. Nipponbare) and O. rufipogon. Journal of Agricultural Science, 7(2) 99-105. http://dx.doi.org/10.5539/jas.v7n2p99

Azizi, F., Rezai, A. M., \& Saeidi, G. (2006). Generation Mean Analysis to Estimate Genetic Parameters for Different Traits in Two Crosses of Corn Inbred Lines at Three Planting Densities. Journal of Agricultural Science and Technology, 8(2), 153-169.

Badu-Apraku, B. (2006). Estimates of genetic variances in Striga resistant extra-early maturing maize populations. Journal of New Seeds, 8, 23-43. http://dx.doi.org/10.1300/J153v08n02_02

Badu-Apraku, B., Lum, A. F., Fakorede, M. A. B., Menkir, A., Chabi, Y., The, C., ... Agbaje, S. (2008). Performance of cultivars derived from recurrent selection for grain yield and Striga resistance in early maize. Crop Science, 48, 99-112. http://dx.doi.org/10.2135/cropsci2007.01.0060

Badu-Apraku, B., Fakorede, M. A. B., \& Menkir, A. (2009). Recurrent selection for Striga resistance in early and extra-early maize populations in West Africa. Africa Crop Science Conference Proceedings (Vol. 9, pp. 415-424).

Badu-Apraku, B., \& Akinwale, R. O. (2011). Cultivar evaluation and trait analysis of tropical early maturing maize under Striga-infested and Striga-free environments. Field crops Research, 121, 186-194. http://dx.doi.org/10.1016/j.fcr.2010.12.011

Badu-Apraku, B., Yallou, C. G., \& Oyenkunle, M. (2013). Genetic gains from selection for high grain yield and Striga resistance in early maturing maize cultivars of three breeding periods under Striga-infested and Striga-free environments. Field Crops Research, 147, 54-67. http://dx.doi.org/10.1016/j.fcr.2013.03.022

Bennetzen, J. L., Gong, F., Xu, J., Newton, C., \& de Oliveira, A. C. (2000). The study and engineering of resistance to the parasitic weed Striga in rice, sorghum and maize. In B. I. G. Haussmann, D. E. Hess, M. L. Koyama, L. Grivet, H. F. W. Rattunde \& H. H. Geiger (Eds.), Breeding for Striga resistance in cereals (pp. 197-205). Ibadan, Nigeria: Margraf Verlag. 
Berner, D. K., Kling, J. G., \& Singh, B. B. (1995). Striga research and control: A perspective from Africa. Plant Diseases, 79, 652-660. http://dx.doi.org/10.1094/PD-79-0652

Dogget, H. (1988). Tropical Agricultural Series: Sorghum (2nd ed.). Longman Scientific and Technical, Essex, England.

Ejeta, G., Butler, L. G., \& Babiker, A. G. (1992). New approaches to the control of Striga. Striga Research at Purdue University, Research Bulletin. Agricultural Experiment Station, Purdue University, West Lafayette, IN.

Ejeta, G., Butler, L. G., Hess, D. E., Obilana, T., \& Reddy, B. V. (1997). In Rosenow et al. (Eds.), Breeding for Striga resistance in sorghum (pp. 504-516). Proceedings of the International conference on genetic improvement of sorghum and pearl millet Lubbock. TX. Sep. 23-27, 1996. USAID Title XII Collaborative Research Support Program on Sorghum and Pearl Millet (INTSORMIL) and international Crops Research Institute for the Semi-Arid Tropics (ICRISAT), publication 97-5.

Ejeta, G., Mohammed, P., Rich, A., Melake, B., Housley, T. L., \& Hess, D. E. (2000). Selection for specific mechanisms of resistance to Striga in sorghum. Breeding for Striga resistance in cereals (pp. 103-118). Proceedings of a Workshop, IITA, Ibadan, Nigeria. Aug. 16-20, 1999. Margraf Verlag, Weikersheim, Germany.

Ejeta, G. (2007). The Striga scourge in Africa: A growing pandemic. In G. Ejeta \& J. Gressel (Eds.), Integrating New Technologies for Striga Control (pp. 3-16). World Scientific Conference, Singapore.

Gamble, E. E. (1962). Gene effects in corn (Zea mays L.): I. Separation and relative importance of gene effects for yield. Canadian Journal Plant Science, 42, 339-348. http://dx.doi.org/10.4141/cjps62-049

Gethi, J. G., \& Smith, M. E. (2004). Genetic responses of single crosses of maize to Striga hermonthica (Del.) Benth. and Striga asiatica (L. Kuntze). Crop Science, 31, 718-723.

Gurney, A. L., Grimanelli, D., Kanampiu, F., Hoisington, D., Scholes, J. D., \& Press, M. C. (2003). Novel sources of resistance to Striga hermonthica in Trypsacum dactyloides, a wild relative of maize. New Phytologist, 160, 557-568. http://dx.doi.org/10.1046/j.1469-8137.2003.00904.x

Gurney, A. L., Slate, J., Press, M. C., \& Scholes, J. D. (2006). A novel form of resistance in rice to the angiosperm parasite Striga hermonthica. New Phytologist, 169, 199-208. http://dx.doi.org/10.1111/j.1469-8137.2005.01560.x

Hallauer, A. R., \& Miranda, J. B. (1988). Heredity variance: Mating design. In Hallauer \& Miranda (Eds.), Quantitative genetics in maize breeding (pp. 45-114). Iowa State Univ. Press, Ames.

Harahap, Z., Ampong Nyarko, K., \& Olela, J. C. (1993). Striga hermonthica resistance in upland rice. Crop Protection, 12, 229-231. http://dx.doi.org/10.1016/0261-2194(93)90114-X

Haussmann, B. I. G., Hess, D. E., Welz, H. G., \& Geiger, H. H. (2000). Improved methodologies for Breeding Striga resistance sorghums. Field Crops Research, 66, 195-211. http://dx.doi.org/10.1016/S0378-4290(00)00076-9

Haussmann, B. I. G., Hess, D. E., Omanya, G. O., Folkertsma, R. T., Reddy, B. V. S., Kayentao, M., ... Geiger, H. H. (2004). Genomic regions influencing resistance to the parasitic weed Striga hermonthica in two recombinant inbred populations of sorghum. Theoretical and Applied Genetics, 109, 1005-1016. http://dx.doi.org/10.1007/s00122-004-1706-9

Hayman, B. I. (1958). The separation of epistatic from additive and dominance variation in generation means. Heredity, 12, 371-390. http://dx.doi.org/10.1038/hdy.1958.36

Hearne, S. J. (2009). Control-the Striga conundrum. Pest management Science, 65, $603-614$. http://dx.doi.org/10.1002/ps.1735

Hess, D. E., Ejeta, G., \& Butler, L. G. (1992). Selecting sorghum genotypes expressing a quantitative biosynthetic trait that confers resistance to Striga. Phytochemistry, 31, 493-497. http://dx.doi.org/10.1016/0031-9422(92)90023-J

Jaetzold, R., \& Schmitt, H. (1982). Farm Management Handbook of Kenya. Natural conditions and Farm Management Information (Vol. 11A). West Kenya, Nyanza and Western Provinces, Nairobi, Kenya.

Jamil, M., Rodenburg, J., Charnikova, T., \& Bouwmeester, H. J. (2001). Pre-attachment Striga hermonthica resistance of New Rice for Africa (NERICA) cultivars based on low strigolactone production. New 
Phytologist, 192, 964-975. http://dx.doi.org/10.1111/j.1469-8137.2011.03850.x

Karaya, H., Kiarie, N., Mugo, S. N., Kanampiu, F. K., Ariga, E., \& Nderitu, J. (2012). Identification of new maize inbred lines with resistance to Striga hermonthica (Del.) Benth. J. Crop protection, 1, 131-142.

Kling, J. G., Fajemisin, J. M., Badu-Apraku, B., Diallo, A., Menkir, A., \& Melake-Berhan, A. (2000). Striga resistance in maize. In B. I. G. Haussmann, D. E. Hess, M. L. Koyama, L. Grivet, H. F. W. Rattunde \& H. H. Geiger (Eds.), Breeding for Striga resistance in cereals (pp. 103-118). Megraf Verlag, Weikersheim, Germany.

Kim, S. K. (1994). Genetics of maize tolerance to Striga hermonthica. Crop Science, 34, $900-907$. http://dx.doi.org/10.2135/cropsci1994.0011183X003400040012x

Kim, S. K., Akintunde, A. Y., \& Walker, P. (1999). Responses of maize inbreds during development of Striga hermonthica infestation. Maydica, 44, 333-339.

Kiruki, S., Onek, L. A., \& Limo, M. (2006). Azide-based mutagenesis suppresses Striga hermonthica seed germination and parasitism on maize varieties. African Journal of Biotechnology, 5, 866-870.

Kountche, B. A., Hash, C. T., Dodo, H., Laoualy, O., Sanogo, M. D., ... Haussmann, B. I. G. (2013). Development of a pearl millet Striga resistant gene pool: Response to five cycles of recurrent selection under Striga infested field conditions in West Africa. Field Crops Research, 154, 82-90. http://dx.doi.org/10.1016/j.fcr.2013.07.008

Lane, J. A., Child, D. V., Moore, T. H. M., Arnold, G. M., \& Bailey, J. A. (1997). Phenotypic characterization of resistance in Zea diploperennis to Striga hermonthica. Maydica, 42, 45-51.

Lynch, M., \& Walsh, B. (1998). Genetics and Analysis of Quantitative Traits. Sinauer Associates, Sunderland, MA.

Maiti, R. K., Ramaiah, K. V., Bisen, S. S., \& Chidley, V. L. (1984). A comparative study of the haustorial development of Striga asiatica (L.) Kuntze on sorghum cultivars. Annals of Botany, 54, 447-457.

Mather, K., \& Jinks, J. L. (1982). Biometrical Genetics (3rd ed.). Chapman and Hall, London. http://dx.doi.org/10.1007/978-1-4899-3406-2

Mbasa, S. (1994). Screening sorghum cultivars for resistance to witchweed (Striga asiatica) in Zimbabwe. Proceedings of SAD.

Menkir, A., \& Kling, J. G. (1999). Effect of reciprocal recurrent selection on grain yield and other traits in two early maturing maize populations. Maydica, 44, 159-165.

Menkir, A. (2006). Assessment of reactions of diverse maize inbred lines to Striga hermonthica (Del.) Benth. Plant Breeding, 125, 131-139. http://dx.doi.org/10.1111/j.1439-0523.2006.01175.x

Menkir, A., Kling, J. G., Badu-Apraku, B., Ibinkule, O. (2006). Registration of 26 tropical maize germplasm lines with resistance to Striga hermonthica. Crop Science, 46, 1007-1009. http://dx.doi.org/10.2135/cropsci2005.0143

Menkir, A., \& Kling, J. G. (2007). Response to recurrent selection for resistance to Striga hermonthica (Del.) Benth. in a tropical maize population. Crop Science, 47, 674-684. http://dx.doi.org/10.2135/cropsci2006.07.0494

Mohamed, A., Ellicott, A., Housley, T. L., \& Ejeta, G. (2003). Hypersensitive response to Striga infection in Sorghum. Crop Science, 43, 1320-1324. http://dx.doi.org/10.2135/cropsci2003.1320

Nagawa, L. (1991). Effects of sowing dates, nitrogen levels and herbicides on the reactions of varieties of sorghum (Sorghum bicolor L.) Moench to Striga hermonthica (MSc. Thesis, p. 102). Agronomy Dept., Ahmadu Bello University, Zaria, Nigeria.

Noubissie, J. B. T., Yadji, H. T., \& Baldena, I. (2012). Screening Sorghum populations for Resistance to Striga hermonthica (Del.) Benth. in Northern Cameroon. Annals of Biology Research, 3, 2357-2364.

Olivier, A., Benhamon, N., \& Leroux, G. D. (1991). Cell surface interactions between sorghum roots and the parasitic weed Striga hermonthica cytochemical aspects of cellulose distribution in resistant and susceptible host tissues. Canadian Journal of Botany, 69, 1679-1690. http://dx.doi.org/10.1139/b91-213

Oswald, A., \& Ransom, J. K. (2004). Response of maize varieties to Striga infestation. Crop Protection, 23, 89-94. http://dx.doi.org/10.1016/S0261-2194(03)00173-X 
Pierce, S., Mbwaga, A. M., Press, M. C., \& Scholes, J. D. (2003). Xenognosin production and tolerance to Striga asiatica infection of high-yielding maize cultivars. Weed Research, 43, 139-145. http://dx.doi.org/10.1046/j.1365-3180.2003.00325.x

Reda, F., \& Kebebe, Y. (1994). Studies on Striga host range and resistance screening in sorghum. African Crop Science, 12(3), 301-307.

Rich, P. J., Grenier, C., \& Ejeta, G. (2004). Striga resistance in the wild relatives of sorghum. Crop Science, 44, 2221-2229. http://dx.doi.org/10.2135/cropsci2004.2221

Rich, P. J., \& Ejeta, G. (2008). Towards effective resistance to Striga in African maize. Plant Signaling Behavior, 3, 1-4. http://dx.doi.org/10.4161/psb.3.9.5750

Rispail, N., Dita, M. A., González Verdejo, C., Pérez-de-Luque, A., Castillejo, M. A., Prats, E., ... Rubiales, D. (2007). Plant resistance to parasitic plants: Molecular approaches to an old foe. New Phytologist, 173, 703-712. http://dx.doi.org/10.1111/j.1469-8137.2007.01980.x

Sauerborn, J. (1991). In J. K. Ransom, L. J. Musselman, A. D. Worsham \& C. Parker (Eds.), Economic importance of Phytoparasites Orobanche and Striga (pp. 137-143). Proceedings of the $5^{\text {th }}$ International symposium on parasitic weeds, CIMMYT, Nairobi, Kenya.

SAS Institute. (2001). Statistical Analysis software (SAS) User's guide. SAS institute, Inc., Cary, NC, USA.

Sharma, J. R. (1998). Statistical and Biometrical Techniques in Plant Breeding (pp. 284-300). New Delhi, India: New Age International.

Sharma, N. K. (2012). OPSTAT online Agricultural Data Analysis.

Shinde, V. K., \& Kulkarni, N. (1982). Genetics of resistance to Striga asiatica in Sorghum (pp. 134-141). Proceedings of the ICRISAT Working Group Meeting on Striga control. Pantancheru, India.

Sprague, G. F., \& Eberhart, S. A. (1977). Corn breeding. In G. F. Sprague (Ed.), Corn and Corn Improvement (2nd ed.), American Society of Agronomy Monograph 18, USA (pp. 305-362).

Swamy Rao, T. (1979). Estimates of gene numbers and heritabilty in okra. Research Bulletin of Marathwada Agriculture University, 3, 44.

Vasudeva Rao, M. J., Chidley, V. L., \& House, L. R. (1982). Genetic control of Striga asiatica in sorghum (p. 22). Proceeding of the ICRISTAT Working Group Meeting on Striga control. Patancheru, India.

Verkleij, J. A. C., \& Kuiper, E. (2000). Various approaches to controlling root parasitic weeds. Biotechnology Development and Monitoring, 41, 16-29.

Vogler, R. K., Ejeta, G., \& Butler, L. G. (1996). Inheritance of low production of Striga germination stimulant in sorghum. Crop Science, 36, 1185-1191. http://dx.doi.org/10.2135/cropsci1996.0011183X003600050020x

Wang, J. K., Gai, J. Y., \& Zhang, Y. M. (2000). Identification of two major genes plus polygenes mixed inheritance model of quantitative traits in B1 and B2 and F2. Journal of Biomathematics, 15, 358-366.

Weber, C. R. (1950). Inheritance and inter-relation of some agronomic and chemical characters in soybeans, Glycine $\max \times$ G. ussuriensis. Iowa Agriculture Experimental Station Research. Bulletin, 374, 765-816.

Yi-Hong, W., Hari, D., \& Chittaranjan, K. (2014). Genetics, Genomics and Breeding of sorghum. CRC Press.

\section{Copyrights}

Copyright for this article is retained by the author(s), with first publication rights granted to the journal.

This is an open-access article distributed under the terms and conditions of the Creative Commons Attribution license (http://creativecommons.org/licenses/by/3.0/). 